\title{
Pengaruh Penggunaan Lembar Aktivitas Siswa Berbasis Metode Penemuan Terbimbing terhadap Peningkatan Kemampuan Representasi Matematis Siswa
}

\author{
Annajmi $^{*}$ dan Lusi Eka Afri ${ }^{2}$ \\ Program Studi Pendidikan Matematika, Universitas Pasir Pengaraian \\ Jalan Tuanku Tambusai, Kumu, Pasir Pengaraian Riau 28457, Indonesia \\ 1*annajminajmi86@gmail.com \\ 2lusiekaafri13@gmail.com
}

Artikel diterima: 29-11-2018, direvisi: 22-01-2019, diterbitkan: 31-01-2019

\begin{abstract}
Abstrak
Penelitian ini bertujuan untuk mengetahui ada atau tidaknya pengaruh penggunaan Lembar Aktivitas Siswa (LAS) berbasis metode penemuan terbimbing terhadap kemampuan representasi matematis siswa SMP. Penelitian ini merupakan penelitian quasi eksperimen dengan Pretest Posttest Control Group Design. Penelitian ini dilakukan di SMPN 3 Rambah pada siswa kelas VII. Data yang dikumpulkan adalah data peningkatan kemampuan representasi matematis siswa. Instrumen yang digunakan adalah soal essay yang disusun berdasarkan indikator kemampuan representasi matematis. Hasil analisis data menggunakan

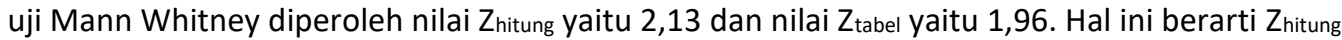
$>Z_{\text {tabel }}$ dengan demikian sesuai kriteria penguhian hipotesis, Ho ditolak. Oleh karena itu dapat disimpulkan bahwa ada pengaruh yang signifikan penggunaan LAS berbasis metode penemuan terbimbing terhadap peningkatan kemampuan representasi matematis siswa SMP. Kata Kunci: lembar aktivitas siswa, penemuan terbimbing, representasi matematis.
\end{abstract}

\section{The Effect of Use of Student Activity Sheets Based on Guided Discovery Method on Increasing Students Mathematical Representation Ability}

\begin{abstract}
This study aims to determine whether or not the influence of the use of Student Activity Sheet (SAS) based on guided discovery methods on the mathematical representation ability of junior high school students. This research was a quasi-experimental study with Pretest Posttest Control Group Design. This research was conducted at SMPN 3 Rambah in class VII students. The data collected was data on improving students mathematical representation abilities. The instrument used was an essay test which was arranged based on indicators of mathematical representation ability. The results of data analysis using the Mann Whitney test obtained a calculated value of 2.13 and a Ztable value of 1.96. This means that Zhitung Z Ztable is thus according to the criteria of hypothesis testing, Ho was rejected. Therefore, it can be concluded that there is a significant effect of the use of SAS based guided discovery method on improving the mathematical representation ability of junior high school students.

Keyword: student activity sheet, guided discovery, mathematical representation.
\end{abstract}




\section{Pendahuluan}

PrMuhsetyo (Alam dan Razak, 2018) menyatakan bahwa pembelajaran sebagai kepada siswa melalui serangkaian kegiatan yang terencana sehingga siswa memperoleh kompetensi tentang bahan matematika yang dipelajari. Pembelajaran matematika yang dilaksanakan di sekolahsekolah seyogyanya adalah pembelajaran student center bukan teacher center. Hal ini sesuai dengan salah satu dasar dikembangkannya kurikulum 2013, sebagaimana yang dijelaskan oleh Mahmudah, (2016) bahwa kurikulum 2013 pola pikir antara lain: pembelajaran berpusat kepada siswa, pembelajaran interaktif, pola pembelajaran aktif, pola pembelajaran kelompok dan pola pembelajaran kritis.

NCTM (2000:29) telah menetapkan kemampuan matematis yang harus dimiliki siswa adalah: (1) problem solving (pemecahan masalah); (2) reasoning and proof (penalaran dan pembuktian); (3) (connections) koneksi; dan (5) (representation) representasi. Depdiknas (Annajmi, 2016) menetapkan bahwa mata pelajaran matematika diantaranya bertujuan agar siswa memiliki kemampuan mengkomunikasikan gagasan dengan simbol, tabel, diagram, atau media lain untuk memperjelas keadaan atau masalah. Kemampuan representasi matematis merupakan satu dari kemampuan yang proses pemberian pengalaman belajar dikembangkan dengan penyempurnaan (communiation) komunikasi; (4)

bisa dikembangkan untuk mencapai tujuan tersebut.

Guru memiliki peran penting dalam menciptakan pembelajaran yang dapat mengembangkan kemampuan berpikir siswa. Sebagaimana yang dinyatakan oleh Slavin (Rosidi, 2016) bahwa dalam implikasi dari teori Piaget yang menyatakan bahwa pembelajaran dipusatkan pada proses berpikir atau proses mental, bukan sekedar pada hasilnya. Berkaitan dengan itu pembelajaran yang dilaksanakan adalah pembelajaran bermakna, sehingga mampu memberikan dampak pada kemampuan berpikir siswa melalui aktivitas proses berpikir siswa. Fuadi (Lisnani dan Asmaruddin, 2018) menyatakan bahwa pembelajaran matematika merupakan kegiatan yang dilakukan agar pembelajaran bermakna yaitu melalui aktivitas mengamati, menanya, mencoba, menalar, menyaji dan mencipta.

Pembelajaran matematika yang dilaksanakan saat ini masih saja terdapat pembelajaran yang dilaksanakan teacher centers. Hal ini tentunya menjadikan proses pembelajaran matematika kurang mengembangkan kemampuan berpikir siswa. Sebagaimana yang dinyatakan oleh Tukan, (Rosidi, 2016) bahwa lemahnya proses pembelajaran di Indonesia lebih mengedepankan filosofi vocal teacher, silent students (guru berbicara, murid diam). Pembelajaran ini menjadikan siswa pasif, siswa menjadi terbatas interaksi baik sesama siswa, guru maupun dengan sumber belajar. Selain itu, kemampuan 
berpikir siswa juga kurang terlatih dalam memecahkan masalah matematis.

Marti (Sundayana, 2013:3) mengungkapkan bahwa objek matematika yang bersifat abstrak tersebut merupakan kesulitan tersendiri yang harus dihadapi siswa dalam mempelajari matematika. Oleh karena itu dengan kajian matematika yang bersifat abstrak diperlukan suatu bentuk representasi yang dapat mempermudah siswa memahami ide-ide matematika yang bersifat abstrak menjadi lebih konkrit dan mudah dipahami.

Vergnaud (Goldin, 2002:207) menjelaskan bahwa representasi merupakan unsur penting dalam suatu teori belajar dan mengajar matematika, hal dikarenakan 1) matematika mempunyai peranan penting dalam mengkonseptualisasikan dunia nyata; 2) matematika membuat homomorphis yang luas yang merupakan penurunan dari struktur hal-hal lain yang pokok. Pentingnya kemampuan representasi matematis juga dapat dilihat dari standar representasi yang ditetapkan oleh NCTM (2000:67) bahwa Instructional rograms from prekindergarten through grade 12 should enable all students to- select, apply, and translate among mathematical representations to solve problems; use representations to model and interpret physical, social, and mathematical phenomena.

Berkaitan dengan itu diperlukan keterampilan dan kemampuan guru dalam menyiapkan suatu perencanaan untuk menciptakan pembelajaran matematika yang efektif, menantang dan mengembangkan kemampuan berpikir siswa. Mulyasa (Annajmi dan Azra, 2017) menyatakan bahwa kreativitas dalam mengembangkan sumber belajar sangat penting, bukan karena keterbatasan fasilitas dan dana dari pemerintah, tetapi merupakan kewajiban yang harus melekat pada setiap guru untuk berkreasi, berinisiatif dan inovatif.

Guru seringkali tidak mengarahkan siswa untuk bisa mereprentasikan dalam bentuk lain. Hal ini senada dengan yang disampaikan Hutagaol, (Annajmi, 2016) bahwa terdapat permasalahan dalam penyampaian materi pembelajaran matematika, yaitu kurang berkembangnya daya representasi matematis siswa, khususnya pada siswa SMP, siswa tidak diberi kesempatan untuk menghadirkan representasinya sendiri tetapi mengikuti apa yang sudah dicontohkan oleh guru sebelumnya. Hal ini menyebabkan siswa memiliki kemampuan berpikir matematis yang rendah, khususnya pada kemampuan representasi matematis.

Perangkat pembelajaran atau perencanaan pembelajaran menjadi bagian penting yang tidak dapat dipisahkan dalam menciptakan proses pembelajaran yang efektif dalam mengembangkan kemampuan berpikir siswa. Menurut (Kurniawati \& Rizkianto) perangkat pembelajaran harus memenuhi kualitas yang baik agar dapat mewujudkan pembelajaran yang efektif dan dapat memotivasi siswa dalam belajar. Perangkat pembelajaran yang dirancang juga perlu

\section{Mosharafa: Jumal Pendidikan Matematika}

Volume 8, Nomor 1, Januari 2019

Copyright $\odot 2019$ Mosharafa: Jurnal Pendidikan Matematika 
memperhatikan aspek aspek kemampuan berpikir tingkat tinggi (Higher Order Thinking Skills).

Purba, dkk (2018) menyatakan bahwa mendesain perangkat pembelajaran sebagai media dalam proses pembelajaran adalah bagian penting yang perlu dilakukan untuk membuat pembelajaran yang efektif dan efisien, sehingga kompetensi yang harus dicapai oleh siswa dapat tercapai. Lembar Aktivitas Siswa (LAS) merupakan salah satu media belajar yang dapat digunakan oleh guru untuk memfasilitasi siswa dalam berinteraksi sesama siswa melalui diskusi kelompok atau bekerja sama. Menurut Johnson dan Johnson, (2004) belajar menggunakan LAS, diharapkankan siswa akan dapat mendominasi dalam memahami konsep melalui bimbingan lembar aktivitas dan bekerja sama dalam kelompok. Berkaitan dengan itu siswa dapat aktif berpikir bersama dalam menghadirkan ide/gagasannya. Hal ini sejalan dengan yang diungkapkan dalam NCTM, (2000) bahwa pembelajaran matematika di kelas menengah, siswa harus terlibat aktif terkait dengan kemampuan menemukan dan menentukan struktur, menduga dan memverifikasi, berpikir tentang hipotesis, memahami sebab akibat, abstraksi dan menarik kesimpulan. Hal ini menjadikan LAS bagian penting dari perangkat pembelajaran sebagai sumber belajar yang langsung digunakan oleh siswa dan guru dalam proses pembelajaran. LAS berbasis metode penemuan terbimbing merupakan salah satu cara yang dapat digunakan 98 untuk mengembangkan kemampuan representasi matematis siswa.

Bruner (Dahar, 2011:79) mengungkapkan bahwa belajar dengan penemuan sesuai dengan pencarian pengetahuan secara aktif oleh manusia dan dengan sendirinya memberikan hasil yang paling baik. Menurut Andarwati dan Hermawati (Annajmi dan Azra, 2017) metode penemuan terbimbing menempatkan guru sebagai fasilitator sehingga guru membimbing siswa hanya jika diperlukan saja. Sementara itu Prasad (2011:32) menjelaskan bahwa metode penemuan terbimbing mendorong siswa untuk berpikir sendiri, belajar sendiri, tanpa harus tergantung penuh kepada guru.

Lembar Aktivitas Siswa (LAS) berbasis metode penemuan terbimbing memungkin siswa untuk berpikir bersama dalam membangun pengetahuannya sendiri melalui aktivitas aktivitas berpikir yang dirancang dalam LAS melalui pertanyaan atau pernyataan yang mengarahkan siswa untuk menghubungkan pengetahuan yang dimilikinya dengan pengetahuan baru yang akan dipelajari. Siswa didorong untuk berpikir sendiri melalui diskusi kelompok, menganalisis bersama sehingga menemukan prinsip, konsep dari materi yang sedang dipelajari.

Archera, Belecina dan Garvida (2015) menyatakan bahwa belajar melalui penemuan terbimbing didasarkan atas sejauhmana keterlibatan siswa dalam aktivitas di kelas dengan bimbingan guru Mosharafa: Jurnal Pendidikan Matematika Volume 8, Nomor 1, Januari 2019 Copyright $\odot 2019$ Mosharafa: Jurnal Pendidikan Matematika 
dalam mengaktifkan proses berpikir siswa. Bimbingan bimbingan guru diberikan melalui pernyataan ataupun pertanyaan yang mengarahkan proses berpikir siswa yang dituangkan dalam LAS. Siswa melakukan aktivitas berpikir bersama untuk memahami, membuat perkiraan, menganalisis, dan menemukan, sehingga diperoleh suatu kesimpulan bersama.

Menurut Senemoglu, (Wulandari, dkk: 2018) bahwa dalam pembelajaran penemuan terbimbing, proses belajar menjadi lebih terarah dengan bimbingan guru, seperti memberikan masalah kepada siswa, dengan bantuan guru, siswa membuat hipotesis, guru memberikan LAS dan arahan kepada siswa sebagai acuan dalam melaksanakan eksperimen, selanjutnya siswa memproses data, menarik kesimpulan dan membuat semacam laporan berdasarkan hasil kegiatan yang sesuai dengan bimbingan guru. Bimbingan dari guru selain dituangkan dalam LAS dalam bentuk pertanyaan atau pernyataan yang mengaktifkan proses berpikir siswa, juga dilakukan secara langsung kepada siswa atau kelompok yang mengalamai kesulitan.

Berdasarkan uraian yang telah disampaikan, maka tujuan dari penelitian ini adalah untuk mengetahui ada atau tidaknya pengaruh penggunaan Lembar Aktivitas Siswa (LAS) berbasis metode penemuan terbimbing terhadap peningkatan kemampuan representasi matematis siswa SMP dalam pembelajaran matematika.

Mosharafa: Jurnal Pendidikan Matematika

Volume 8, Nomor 1, Januari 2019

Copyright $\odot 2019$ Mosharafa: Jurnal Pendidikan Matematika

\section{Metode}

Jenis penelitian ini adalah quasi eksperimen. Penelitian quasi eksperimen digunakan karena pemilihan siswa dalam kelompok eksperimen dan kontrol tidak dipilih secara acak, melainkan menggunakan kelompok yang sudah ada yaitu siswa yang ada pada kelas VII SMPN 3 Rambah.

Desain penelitian quasi eksperimen yang digunakan yaitu pretest postest control group. Siswa kelompok eksperimen diberikan perlakuan (treatment) menggunakan LAS berbasis metode guided discovery learning dan siswa kelompok kontrol diberikan perlakuan (treatment) dengan pembelajaran konvensional.

Data yang dikumpulkan adalah data kemampuan representasi matematis siswa yang diperoleh dari hasil pretes dan postes. Instrumen yang digunakan adalah soal tes kemampuan representasi matematis siswa yang berbentuk essay.

Soal tes disusun sesuai dengan indikator kemampuan representasi matematis siswa, yaitu (1) siswa memiliki kemampuan menyajikan suatu situasi atau masalah yang diberikan dalam bentuk simbol, tabel grafik atau gambar, (2) siswa memiliki kemampuan menyajikan suatu situasi atau masalah yang melibatkan persamaan matematis, dan (3) siswa memiliki kemampuan dalam menyajikan suatu situasi atau masalah dalam bentuk teks tertulis atau kata-kata sendiri.

Hasil tes kemampuan representasi matematis siswa yang diperoleh 
selanjutnya dilakukan penilaian menggunakan pedoman penskoran yang diadaptasi dari Mathematics Instructional Rubrics Middle School Level. Adapun pedoman penskoran hasil tes tersebut disajikan pada Tabel 1 berikut.

Tabel 1.

Rubrik Penilaian Representasi Matematis

\begin{tabular}{|c|c|}
\hline Kriteria Jawaban & Skor \\
\hline Tidak ada jawaban & 0 \\
\hline $\begin{array}{l}\text { - Menunjukkan representasi yang tidak } \\
\text { akurat dan beberapa data atau tidak ada } \\
\text { hubungan yang diperlukan dalam masalah } \\
\text { - Menunjukkan beberapa atau tidak ada } \\
\text { label, simbol operasi, judul dan kunci } \\
\text { untuk jenis representasi yang dipilih } \\
\text { - Menunjukkan kesimpulan yang tidak } \\
\text { benar dari representasi yang ditampilkan. }\end{array}$ & 1 \\
\hline
\end{tabular}

- Menunjukkan representasi yang sebagian akurat dan sebagian data dan sebagian hubungan yang diperlukan dalam masalah

- Menunjukkan sebagian label, simbol operasi, judul dan kunci untuk jenis representasi dipilih

- Menunjukkan kesimpulan yang sebagian benar dari representasi yang ditampilkan.

- Menunjukkan representasi yang hampir akurat dan sebagian data dan sebagian hubungan yang diperlukan dalam masalah

- Menunjukkan hampir semua label, symbol operasi, judul dan kunci untuk jenis representasi yang dipilih

- Menunjukkan kesimpulan kurang lengkap dan hampir benar dari representasi yang ditampilkan.

- Menunjukkan representasi yang benarbenar akurat dan mencakup semua data dan semua hubungan yang diperlukan dalam masalah

- Menunjukkan semua label, symbol operasi, judul dan kunci untuk jenis representasi dipilih

- Menunjukkan kesimpulan dengan lengkap dan benar dari representasi yang ditampilkan.

Data yang diperoleh dari skor pretest dan postest dianalisis untuk mengetahui peningkatan kemampuan pemahaman konsep dan representasi matematik siswa. Besarnya peningkatan dihitung dengan rumus gain ternormalisasi yang dikembangkan oleh Meltzer (2002), yaitu:

$$
(\mathrm{g})=\frac{\text { skor posttest-skor pretes }}{\text { skor ideal-skor pretest }}
$$

Hasil perhitungan gain ternormalisasi kemudian diinterpretasikan dengan menggunakan klasifikasi yang dinyatakan oleh Hake (1999), yaitu:

Tabel 2.

Peningkatan Kemampuan Representasi Matematis

\begin{tabular}{|c|c|}
\hline Interval & Kategori \\
\hline$g \geq 0,7$ & Tinggi \\
\hline $0,3 \leq g \leq 0,7$ & Sedang \\
\hline $\mathrm{g} \leq 0,3$ & Rendah \\
\hline peningkatan & kemampua \\
\hline
\end{tabular}
representasi matematis siswa, selanjutnya 2 dilakukan analisis inferensial untuk menjawab rumusan masalah. Pengujian dilakukan menggunakan uji mann whitney. Uji ini digunakan karena data tidak berdistribusi normal.

\section{Hasil dan Pembahasan}

\section{A. Hasil Tes Kemampuan Representasi Matematis}

Adapun hasil tes kemampuan representasi matematis siswa disajikan pada Tabel 3.

Tabel 3.

Hasil Tes Kemampuan Representasi Matematis

\begin{tabular}{lcc}
\hline Kelompok & $\begin{array}{c}\text { Rata-rata } \\
\text { Pretes }\end{array}$ & $\begin{array}{c}\text { Rata-rata } \\
\text { Postes }\end{array}$ \\
\hline Eksperimen & 16,34 & 74,23 \\
\hline Kontrol & 19,55 & 68,84 \\
\hline
\end{tabular}

Tabel 3. Menunjukkan bahwa rata-rata hasil postes kemampuan representasi matematis siswa kelompok eksperimen 
lebih tinggi dari pada kelompok kontrol. Selisih rata-rata kelompok eksperimen dan kontrol adalah 5. Selain itu juga dapat dilihat hasil postes lebih tinggi dari pada hasil pretes. Hal ini memberikan gambaran adanya peningkatan kemampuan representasi matematis siswa yang lebih tinggi pada siswa yang menggunakan lembar aktivitas siswa berbasis metode penemuan terbimbing daripada kelompok kontrol yang pembelajarannya konvensional.

\section{B. Hasil Tes Kemampuan Representasi Matematis setiap Indikator}

Adapun kemampuan representasi matematis siswa pada masing-masing indikator dapat dilihat pada Tabel 4.

Tabel 4.

Hasil Pretes Kemampuan Representasi Matematis

\begin{tabular}{|c|c|c|}
\hline Indikator & $\begin{array}{l}\text { Pretes } \\
\text { Kontrol }\end{array}$ & $\begin{array}{c}\text { Pretes } \\
\text { Eksperimen }\end{array}$ \\
\hline $\begin{array}{l}\text { Menyajikan data atau } \\
\text { informasi dari suatu } \\
\text { representasi ke } \\
\text { representasi diagram, } \\
\text { grafik,dan tabel }\end{array}$ & 38,46 & 33,65 \\
\hline $\begin{array}{l}\text { Menuliskan langkah- } \\
\text { langkah penyelesaian } \\
\text { masalah matematis } \\
\text { dengan kata-kata }\end{array}$ & 0 & 0 \\
\hline $\begin{array}{l}\text { Menuliskan langkah- } \\
\text { langkah penyelesaian } \\
\text { masalah matematis } \\
\text { dengan kata-kata }\end{array}$ & 20,19 & 15,38 \\
\hline Rata-Rata Keseluruhan & 19,55 & 16,34 \\
\hline
\end{tabular}

Berdasarkan Tabel 4. memperlihatkan kemampuan representasi matematis siswa pada masing masing indikator untuk kelompok kontrol. Hal ini menunjukkan kemampuan representasi matematis siswa pada kedua kelompok masih rendah. Soal yang diberikan untuk indikator menyelesaikan masalah dengan melibatkan ekspresi matematis persentase ketercapaiannya masih $0 \%$, indikator ketiga menuliskan langkah-langkah penyelesaian masalah matematis dengan kata-kata dari soal yang diberikan hanya 20,19\% untuk kelompok kontrol dan $15,38 \%$ untuk kelompok eksperimen. Sedangkan untuk indikator pertama menyajikan data atau informasi dari suatu representasi ke representasi diagram, grafik, dan tabel terdapat 38,46\% untuk kelompok kontrol dan 33,65\% untuk kelompok eksperimen. Hal ini memberikan gambaran bahwa representasi siswa kedua kelompok dapat dikatakan sama atau masih rendah, khususnya pada representasi yang melibatkan persamaan atau eksperesi matematis dan penjelasan dalam bentuk teks tertulis atau kata-kata.

Tabel 5.

Hasil Postes Kemampuan Representasi Matematis

\begin{tabular}{|c|c|c|}
\hline Indikator & $\begin{array}{l}\text { Postes } \\
\text { Kontrol }\end{array}$ & $\begin{array}{c}\text { Postes } \\
\text { Eksperimen }\end{array}$ \\
\hline $\begin{array}{l}\text { Menyajikandata atau } \\
\text { informasi dari suatu } \\
\text { representasi ke } \\
\text { representasi diagram, } \\
\text { grafik,dan tabel }\end{array}$ & 87,50 & 89,42 \\
\hline $\begin{array}{l}\text { Menyelesaikan } \\
\text { masalah dengan } \\
\text { melibatkan ekspresi } \\
\text { matematis }\end{array}$ & 47,60 & 53,37 \\
\hline $\begin{array}{l}\text { Menuliskan langkah- } \\
\text { langkah penyelesaian } \\
\text { masalah matematis } \\
\text { dengan kata-kata }\end{array}$ & 80,77 & 87,5 \\
\hline Rata-rata keseluruhan & 71,96 & 76,76 \\
\hline
\end{tabular}

Berdasarkan Tabel 5 dapat dilihat hasil postes kemampuan representasi matematis siswa untuk masing masing indikator pada kedua kelompok. Rata-rata 
kemampuan representasi matematis kelompok eksperimen lebih tinggi dari pada kelompok kontrol. Indikator pertama yang menyajikan data atau informasi dari suatu representasi ke representasi diagram, grafik dan tabel diperoleh selisih kelas eksperimen dan kontrol yaitu 1,92, indikator kedua menyelesaikan masalah dengan melibatkan ekspresi matematis dari soal yang diberikan selisih rata-rata antara kelompok eksperimen dan kontrol yaitu 5,77, sedangkan untuk indikator ketiga menuliskan langkah-langkah penyelesaian masalah matematis dengan kata-kata selisih rata-ratanya secara dari soal yang diberikan adalah 6,73. Hal ini memberikan gambaran bahwa adany peningkatan kemampuan representasi matematis siswa dalam menyelesaikan soal-soal yang diberikan dari pembelajaran matematika yang menggunakan Lembar Aktivitas Siswa (LAS) berbasis metode penemuan terbimbing.

\section{Peningkatan Representasi Matematis}

Adapun peningkatan kemampuan representasi matematis siswa sesuai klasifikasinya, disajikan pada Tabel 6.

Tabel 6.

Peningkatan Kemampuan Representasi Matematis

\begin{tabular}{lccc|}
\hline Interval & Ekperimen & Kontrol & Kategori \\
\hline$g \geq 0,7$ & 18 & 14 & Tinggi \\
\hline $0,3 \leq g \leq 0,7$ & 6 & 11 & Sedang \\
\hline $\mathrm{g} \leq 0,3$ & 2 & 1 & Rendah \\
\hline Jumlah & 26 & 26 & \\
\hline Rata-rata & 0,62 & 0,69 &
\end{tabular}

Berdasarkan Tabel 6. dapat dilihat bahwa peningkatan kemampuan representasi matematis siswa kelompok ekperimen lebih tinggi daripada kelompok kontrol. Kelompok eksperimen terdapat 2 orang atau $7,69 \%$ yang peningkatannya pada kategori rendah, dan kelompok kontrol ada 1 orang atau 3,85\%, namun demikian untuk kategori sedang kelompok kontrol ada 11 orang atau 42,31\% dan kelompok eksperimen ada 6 orang atau 23,07\%, sedangkan pada kategori tinggi kelompok eksperimen ada 18 orang atau 69,23\% dan kelompok kontrol ada 14 orang atau $53,84 \%$. Selain itu, dapat juga dilihat rata-rata nilai gain (peningkatan) kemampuan kemampuan representasi matematis siswa kelompok eksperimen lebih tinggi dari kelompok kontrol. Hal ini memberikan gambaran bahwa adanya peningkatan kemampuan representasi matematis siswa kelompok eksperimen yang lebih baik dari pada peningkatan kemampuan representasi matematis siswa kelompok kontrol.

\section{Pengujian Hipotesis}

Pengujian hipotesis dilakukan untuk menjawab rumusan masalah, yaitu apakah ada atau tidak pengaruh penggunaan Lembar Aktivitas Siswa (LAS) berbasis metode penemuan terbimbing terhadap peningkatan kemampuan representasi matematis siswa. Hasil uji normalitas sebagai uji prasyarat dari pengujian ini disajikan pada Tabel 7.

Tabel 7.

Hasil Uji Normalitas Data N-Gain

\begin{tabular}{lcc|}
\hline Kelompok & Lhitung & Ltabel \\
\hline Eksperimen & 0,85 & 0,174 \\
\hline Kontrol & 0,27 & 0,174 \\
\hline
\end{tabular}

Tabel 7. memperlihatkan bahwa pada kedua kelompok memiliki nilai Lhitung >

Mosharafa: Jumal Pendidikan Matematika Volume 8, Nomor 1, Januari 2019 Copyright $\odot 2019$ Mosharafa: Jurnal Pendidikan Matematika 
LTabel. Hal ini kelompok eksperimen dan kontrol memiliki data tidak berdistribusi normal.

Pengujian hipotesis dilanjutkan dengan uji kesamaan rata-rata menggunakan uji Mann Whitney. Hasil perhitungan analisis data diperoleh nilai $Z_{\text {hitung }}=2,13>Z_{\text {tabel }}=$ 1,96 maka $\mathrm{H}_{0}$ ditolak. Hal ini berarti dapat simpulkan bahwa adanya pengaruh penggunaan Lembar Aktivitas Siswa (LAS) berbasis metode penemuan terbimbing terhadap peningkatan kemampuan representasi matematis.

\section{E. Pembahasan}

Hasil analisis data kemampuan representasi matematis, telah memperlihatkan adanya pengaruh penggunaan LAS berbasis metode penemuan terbimbing terhadap peningkatan kemampuan representasi matematis siswa. Rata-rata peningkatan kemampuan representasi kelompok eksperimen lebih tinggi dari pada kelompok kontrol. Hasil pengujian hipotesis juga menunjukkan nilai Zhitung yang lebih besar dari Ztabel, yang disimpulkan hipotesis diterima, bahwa adanya pengaruh penggunaan Lembar Aktivitas Siswa (LAS) terhadap peningkatan kemampuan representasi matematsi siswa.

Peningkatan ini tentunya tidak terlepas dari penggunaan LAS berbasis metode penemuan terbimbing yang digunakan dalam proses pembelajaran. LAS yang digunakan membantu siswa untuk mengembangkan kemampuan berpikirnya melalui serangkaian tahap tahap metode penemuan terbimbing yang dituangkan dalam bentuk LAS. Siswa diarahkan untuk membangun sendiri pengetahuannya dengan pertanyaan pertanyaan ataupun pernyataan pernyataan dalam LAS sehingga siswa mampu mengaitkan pengetahuan yang diketahuinya dengan pembelajaran yang dipelajari. Siswa saling berinteraksi bersama anggota kelompok dan berbagi ide/gagasan dalam mendiskusikan materi dalam LAS. Ide/gagasan tersebut dituangkan dalam bentuk gambar, simbol, ataupun persamaan matematis sesuai dengan arahan yang diberikan guru dalam LAS. Guru memfasilitasi kelompok selama diskusi dengan memberikan bantuan atau bimbingan seperlunya bagi siswa yang mengalami kesulitan tanpa memberi tahu langsung, melainkan memberikan arahan dan penjelasan kepada siswa untuk memahami konsep yang sedang dipelajari. Hal ini memberikan keterlibatan siswa secara aktif dalam pembelajaran dan proses berpikir siswa menjadi lebih aktif. Sebagaimana yang dijelaskan Achera, Belecina dan Garvida, (2015) bahwa pembelajaran penemuan terbimbing dilaksanakan berdasarkan sejauhmana keterlibatan siswa dalam aktivitas di kelas dengan bimbingan dari guru dalam rangka mengaktifkan proses berpikir siswa.

Pembelajaran yang dilaksanakan menggunakan LAS berbasis metode penemuan terbimbing tersebut memberikan ruang yang lebih luas kepada siswa untuk aktif berpendapat dalam memahami dan menyelesaikan

\section{Mosharafa: Jurnal Pendidikan Matematika}


permasalahan yang disajikan dalam LAS sesuai dengan proses berpikirnya. Pendapat/ide/gagasan tersebut disajikan dalam bentuk gambar, simbol, persamaan ataupun kata-kata dalam bentuk tesk tertulis yang merupakan bagian penting dari kemampuan representasi matematis. Serangkaian kegiatan tersebut akan sangat membantu siswa dalam mengembangkan kemampuan representasi matematisnya. Hal ini sejalan dengan yang dinyatakan oleh Salazar (Achera, Belecina dan Garvida, 2015) bahwa siswa akan belajar lebih baik apabila diberi kesempatan untuk berpikir lebih jauh, mencapai lebih banyak pengetahuan, ketika mereka berdiskusi bersama daripada hanya membaca dan mendengar.

Berikut contoh hasil kerja siswa menggunakan LAS yang diberikan.

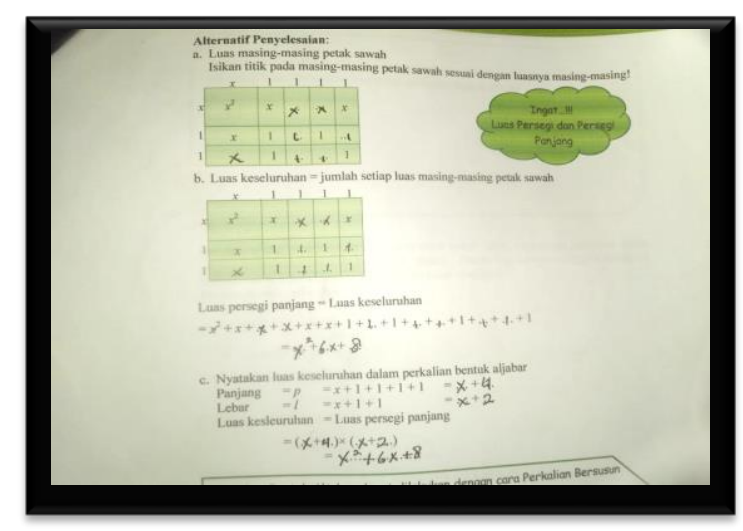

Gambar 1. Contoh Hasil Kerja Siswa.

Gambar 1 salah satu contoh hasil lembar aktifitas siswa yang yang menunjukkan bahwa metode penemuan terbimbing dapat dimunculkan untuk menghasilkan penemuan melalui bimbingan guru. Proses berpikir siswa yang dikembangkan guru melalui langkah langkah yang disajikan dalam LAS, dimana dalam menentukan perkalian bentuk aljabar $(a+b)^{2}=a^{2}+2 a b+b^{2}$ siswa diajak merepresentasikannya dalam bentuk gambar dan simbol sebelum ke bentuk yang umumnya. Proses penemuan suatu konsep perkalian bentuk aljabar. Serangkaian aktivitas berpikir siswa yang dibimbing oleh guru melalui bimbingan Guru kepada siswa untuk menghasilkan penemuan dengan melakukan pemodelan matematika yang dituangkan dalam LAS. Pembelajaran menjadi lebih bermakna dan berorientasi pada siswa. Sebagaimana yang dikemukakan oleh Kenedy, Tipss dan Johnson (2005) bahwa pembelajaran matematika akan bermakna apabila berorientasi pada siswa.

\section{Penutup}

Peningkatan kemampuan representasi matematis siswa melalui pembelajaran matematika menggunakan Lembar Aktivitas Siswa (LAS) berbasis metode penemuan terbimbing. Hal ini dapat dilihat bahwa peningkatan kemampuan representasi matematsi siswa kelompok eksperimen lebih tinggi daripada kelompok kontrol.

Guru matematika untuk bisa menyiapkan bahan ajar berupa lembar aktivitas siswa berbasis metode penemuan terbimbing guna meningkatkan kemampuan representasi matematis siswa dan LAS-LAS lainnya yang bisa membantu siswa untuk mengembangkan kemampuan berpikir matematisnya. Selain itu kepada 
penelitian lainnya untuk bisa melanjutkan penelitian yang serupa karena dalam penelitian ini tentunya masih terdapat kekurangan dan juga menggunakan metode atau model pembelajaran lainnya terhadap kemampuan berpikir matematis lainnya.

\section{UCAPAN TERIMA KASIH}

Ucapan terima kasih disampaikan kepada Dirjen Riset dan Pengabdian kepada Masyarakat (DRPM) Pendanaan Tahun 2018 Kementerian Riset Teknologi dan Pendidikan Tinggi.

\section{Daftar Pustaka}

Achera, L.J, Belecina, R.R dan Garvida, M.D. (2015). The Effect of Group Guided Discovery Approach on The Performance of Students in Geometry. International Journal of Multidiciplinary Research and Modern Eductaion (IJMRME) 1(2),331-342

Alam, Z.I. dan Razak, F. (2018). Pengembangan Lembar Kegiatan Siswa Berbasis Metode Penemuan Terbimbing untuk Pembelajaran Matematika pada Siswa Kelas XII SMA Negeri 1 Segeri. Mosharafa: Jurnal Pendidikan Matematika, 7(1), 1-11

Annajmi, dan Azra, A. (2017). Pengembangan Lembar Kerja Siswa Berbasis Metode Penemuan Terbimbing untuk Meningkatkan Kemampuan Pemahaman Konsep Matematik Siswa Kelas VII SMP Islam Kepenuhan Kabupaten Rokan Hulu. Jurnal Eksakta Pendidikan, 1(1), 39-46
Annajmi. (2016). Peningkatan Kemampuan Representasi Matematik Siswa SMP Melalui Metode Penemuan Terbimbing Berbantuan Software Geogebra di SMPN 25 Pekanbaru. Jurnal Ilmiah Edu Research 5 (2), 67 74

Dahar, R.W. (2011). Teori-teori Belajar dan Pembelajaran. Jakarta: Erlangga

Goldin, (2002). Representation in Mathematical Learning and Problem Solving. Handbook of International Research in Mathematics Education. London: Lawrence Erlbaum Associates, Year Book.

Hake, R. R. (1999). Interactive-Engagement vs Traditional Methoeds: A SixThousand-Student Survey of Mechanics Test Data for Introductoru Physics Courses. American Journal of Physics.

Kurniawati, V dan Rizkianto, I. (2018). Pengembangan Perangkat

Pembelajaran Matematika Berbasis Guided Inquiry dan Learning Trajectory Berorientasi pada Kemampuan Pemecahan Masalah. Mosharafa: Jurnal Pendidikan Matematika, 7(3), 369-380

Lisnani, dan Asmaruddin, S.N. (2018). Desain Buku Aajar Matematika Bilingual Materi Bangun Datar Menggunakan Pendekatan PMRI Berkonteks Kebudayaan Lokal. Mosharafa: Jurnal Pendidikan Matematika, 7(3), 345-356

Mahmudah, C. (2016). Pengembangan Perangkat Pembelajaran Statistika 
SMP dengan Pendekatan Saintifik. Jurnal Riset Pendidikan Matematika. (3) 2, 173-183.

Meltzer, D.E. (2002). The Relationship Between Mathematics Preparation and Conceptual Learning Gain in Physics: A Possible "hidden variable" in Diagnostic Pretest Scores. American Association of Physics Teachers. Am.J.Phys. 70 (12)

National Council of Teachers of Mathematics. (2000). Principles and Standards for School Mathematics. United State: Nasional Council of Teachers of Mathematics, Inc.

Prasad, K.S, (2011). Learning Mathematics by Discovery. Academic Voices A Multidisciplinary Journal 1 (1)

Purba, D. G. I, Surya, E, Manullang, M, Asmin. (2018). The Effect of Students Worksheet in the Model of Discovery Learning Againts the Students Ability of Reasoning and Mathematical Communication in the Faculty of Mathematics and Natural Science of State University of Medan. International Journal of Science: Basic and Aplied Research (IJSBAR) 37(3), 70-82

Rosidi, I. (2016). Pengembangan Lembar Kegiatan Siswa Berorientasi Pembelajaran Penemuan Terbimbing (Guided Discovery Learning) untuk Melatihkan Keterampilan Proses Sains. Jurnal Pena Sains 3(1)
Sundayana, R. (2013).
Media

Pembelajaran Matematika. Bandung: Alfabeta
Wulandari, I G.A.P.A, Sadijah, C. Asari, A.R, dan Rahardjo, S. (2018). Modified Guided Discovery Model: A conceptual Framework for Designing Learning Model Using Guided Discovery to Promote Students Analytical Thinking Skills. $2^{\text {nd }}$ International Conference on Statistics, Mathematics, teaching dan Research, Journal of Physics: Conf.Series.

\section{Riwayat Hidup PENULIS}

\section{Annajmi, M.Pd.}

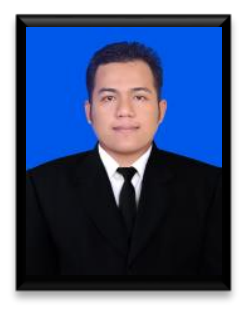

Lahir di Muara Rumbai, pada tanggal 06 November 1986. Staf pengajar di Universitas Pasir Pengaraian. Studi S1 Pendidikan Matematika Universitas Islam Riau, Pekanbaru, lulus tahun 2009; S2 Pendidikan Matematika, Universitas Negeri Medan, Medan, lulus tahun 2015.

\section{Lusi Eka Afri, M.Si.}

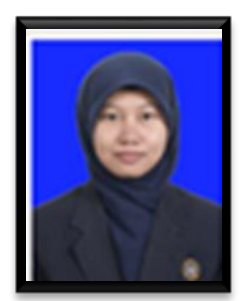

Lahir di Tanah Datar, pada tanggal 01 April 1987. Staf pengajar di Universitas Pasir Pengaraian. Studi S1 Matematika Universitas Negeri Padang, Padang, lulus tahun 2009; S2 Statistika, Bogor, lulus tahun 2012. 